Copyright (C) 2015 by Academic Publishing House Researcher

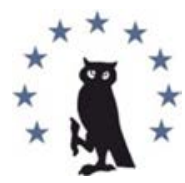

Published in the Russian Federation

European Researcher

Has been issued since 2010.

ISSN 2219-8229

E-ISSN 2224-0136

Vol. 94, Is. 5, pp. 381-388, 2015

DOI: 10.13187/ er.2015.94.381

www.erjournal.ru

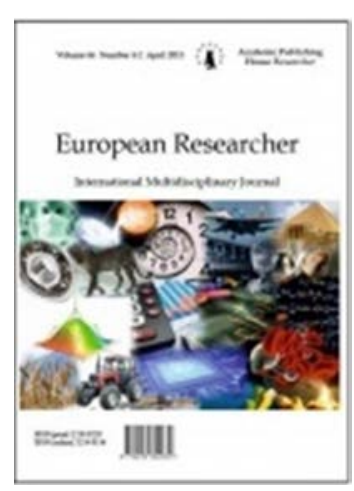

Pedagogical sciences

Педагогические науки

UDC 37

\title{
Cultural Mythology Analysis of Media texts in the Classroom at the Student Audience
}

\author{
Alexander Fedorov \\ Anton Chekhov Taganrog Institute, Russian Federation \\ branch of Rostov State University of Economics \\ Prof. Dr. (Pedagogy) \\ E-mail: mediashkola@rambler.ru
}

\begin{abstract}
The author of this article presents the cultural mythology analysis of media texts: identification and analysis of mythologizing (including in the framework of the so-called folk sources - fairy tales, urban legends, etc.) plot, those types of characters, etc. in media texts. In particular, the audience (for example, students) offered by critical analysis to answer the question why so many entertainment media texts so popular with a mass audience? The author thinks that the media texts relating to the mass / popular culture, have success with the audience is not due to the fact that they supposedly only target people with low aesthetic taste, subject to psychological pressure, easy to believing the lie, etc., but because their authors respect and learning needs of the audience, including - information, compensatory, hedonistic, recreational, moral, aesthetic, etc.

Keywords: cultural mythology analysis, media, media texts, media education, media literacy, media competence, students.

\section{Introduction}

Cultural mythology analysis of media texts: identification and analysis of mythologizing (including in the framework of the so-called folk sources - fairy tales, "urban legends", etc.) plot, those types of characters, etc. in media texts. In particular, the audience (for example, students) offered by critical analysis to answer the question why so many entertainment media texts so popular with a mass audience?

Of course, the media texts relating to the mass / popular culture, have success with the audience is not due to the fact that they supposedly only target people with low aesthetic taste, subject to psychological pressure, easy to believing the lie, etc., but because their authors respect and learning needs of the audience, including - information, compensatory, hedonistic, recreational, moral, aesthetic, etc.

The development of modern society absolute inevitably leads to the formation of a special type of mass culture - commercial, and this culture based on modern technologies of fundamental
\end{abstract}


human need for harmonization of the psychic life of the people [Razlogov, 1991, p.10], and mass culture "stands today as a means of implementation is not so much hedonistic and recreational as identification and adaptation strategies, consolidating the existing social hierarchy in society through the symbolic significance of cultural consumption and contributing to the stabilization of the social system through the construction of a special virtual reality"[Kostina, 2006, p.18].

At the same time, mass culture, is inconceivable without the media - a natural part of contemporary culture as a whole, to which belongs the majority of all new in the world of media texts. It can be regarded as an effective way to involve the masses of readers, listeners and viewers in a variety of cultural processes; as a phenomenon that is born of the latest technology (primarily communication), a global integration and globalization (destruction of local communities, and the erosion of regional and national borders, etc.).

Such a definition of the mass (popular) culture, in my opinion, logically fits into the context of the functioning of the media - the systematic dissemination of information (via the media, print, television, radio, film, sound / video, Internet) among the "numerically large, dispersed audiences for approval spiritual values and providing ideological, economic or organizational impact on the estimates, opinions and behavior of the people" [Philosopher Dictionary, 1983, p. 348].

However, the known and the approach that separates the mass and popular culture [Kostina, 2006, p.51]. In my opinion, this kind of word game. In my understanding of mass culture and pop culture - synonyms, for which, indeed, may be "modern mythology with its undivided real and ideal, with its appeal not to the knowledge, the faith, not to consciousness and the unconscious, with its dissolution of the individual in the sphere of the collective unconscious, syncretic unity of the individual and society that provides the necessary recreational potential. Hence - the thrust of popular culture stereotypes, image, code of conduct, cliché characters associated with the mythological structure of consciousness and gravitating to the archaic cultural layers"[Kostina, 2006, p.94].

\section{Materials and methods}

V.Y. Propp [Propp, 1976; 1998], N.M. Zorkaya [Zorkaya, 1981; 1994] M.I. Turovskaya [Turovskaya, 1979], O.F. Nechay [Nechay, 1993] M.V. Yampolsky [Yampolsky, 1987], and others researchers have shown convincingly that for the total success of the works of mass culture needs calculation of their creators on the type of folk aesthetic perception, and the "archetypes of fairy tales and legends, and their respective archetypes folk perception, meeting, give the effect of the integral mass success favorites" [Zorkaya, 1981, p.116].

The researchers have repeatedly noted the continuity of folklore, fairy tales, legends and myths. For example, V. Propp was convinced that from a historical point of view, a fairy tale in their morphological fundamentals represents a myth [Propp, 1998, p.68]. Moreover, the "fairy tale and myth sometimes so completely may coincide with each other, in ethnography and folklore such myths are often called fairy tales [Propp, 1998, p.124].

Indeed, the success of the audience is very closely associated with the mythological layer of the product. "Strong" genres - thriller, fantasy, western - always based on "strong" myths "[Yampolsky, 1987, p.41]. Unusual relationship, but "real" events - one of the basic archetypes (based on underlying psychological structures that affect the conscious and subconscious) fairy tales, legends, - is of great importance for the mass popularity of media texts.

In this context, A.Kostina suggests that "the subject of popular culture serves a special professional group, create artifacts in accordance with the laws of social psychology and market relations, the bearer of its values is the same person weight - undifferentiated entity with unexpressed personal principle, which features an uncritical perception and assessments, manageability, spiritual infantilism"[Kostina, 2006, p.19]. In my opinion, these arguments are logical in the first part, relating to the creators of popular culture texts. The studies of media sociologists and educators [Zorkaya, 1981; 1994; Turovskaya, 1979; Nechay, 1993; Fedorov, 2001, and others] argue that the audience of mass culture differentiated, heterogeneous, divided into different types, and in many cases it is impossible to speak about audience as a totally infantile, manageable and uncritical.

Part of active consumers of mass / popular culture is very critical and meticulously monitors implausible, in their view, fragments of (media) texts. Another part of the audience attaches special importance to the moral evaluation of the position of the characters and authors. Third, the 
audiences did not become "infantile" and "controlled" looking action-packed entertainment after a hard day's work, easily separated from the world of entertainment media real life...

O.F. Nechay is very true for the essential feature of the mass (popular) culture - the adaptation of folklore in the forms of society. That is, if the author's "text" ideal emerges through reality (in the center of the plot - the hero-personality), in socio-critical "text" actions of the characters, taken from the life around (common man), the mass culture are ideal norms in real environment (in the center of the story - the super hero) [Nechay, 1993, p.11-13].

As an example, I have the focus on textual analysis by V. Propp, where he successfully combined fairy tale's plot and narrative (including the analysis of the characters, stereotypes, cultural mythology), structural, semiotic, identification and content analysis.

Examining hundreds of fairy stories, V. Propp identified 31 types of major events and the characters with a limited set of roles (seven key characters and seven key roles), between which are distributed in a certain way the characters with their specific functions. Each of the seven actors / roles (the hero, the false hero, the sender, the assistant, the antagonist / villain, the donor, the princess or her father), has a range of actions, ie. one or more functions [Propp, 1998, p.24 -49]. stories:

Here are the result of textual analysis of events / functions in the fairy tale and mythological

I. A member of the family is away from home (definition: absence).

II. The hero has the ban (definition: ban).

III. The prohibition is violated (definition: a violation).

IV. Antagonist tries to spy (definition - scouting).

V. Antagonist gives a information about his victim (definition - information).

VI. Antagonist is trying to deceive their victims to take possession of it or its property (definition - the catch).

VII. Victim amenable deception and unwittingly helping the enemy (definition - aiding).

VIII. Antagonist causes a family member harm or damage (definition - sabotage).

VIII-a. A family member something is missing, he wanted to have something (definition loss).

IX. Trouble or loss is reported to the hero is requested or orders, send or release him (definition - mediation, the connection point).

$\mathrm{X}$. Seeker agrees to, or decides to resistance (definition - starting resistance).

XI. The hero leaves home (definition - shipping).

XII. The hero is tested, to inquire, is attacked and so forth. Is being prepared than getting them a magical agent or helper (definition - the first function of the donor).

XIII. Hero reacts to actions of future donor (definition - the reaction of the hero): 1) the hero stands (not resistant) test; 2) the hero answers (not responding) to the greeting; 3 ) he has (has not) service deceased; 4) it releases the captive; 5) He spares asking; 6) he commits section and reconciles disputants; 7) Hero has some other service. Sometimes these services are requested, sometimes they are caused by simple kindness hero; 8) character is saved from the attempt on his life, using the tools of hostile creatures to himself; 9) Hero wins hostile creature; 10) The hero agrees to exchange, but immediately applies the magic power.

XIV. In the order of the hero enters a magical agent (definition - supply, receipt of a magical agent).

XV. Hero is transferred, delivered or given to another location (definition - spatial displacement between the two kingdoms).

XVI. The hero and antagonist come into direct struggle (definition - wrestling).

XVII. Hero has the tag (definition - branding, mark).

XVIII. Antagonist is overcome (definition - a victory).

XIX. The initial trouble or shortage is eliminated (definition - the elimination of trouble or shortage).

XX. Hero Returns (definition - return).

XXI. Hero persecuted (definition - the pursuit).

XXII. The hero is saved from prosecution (definition - salvation designation).

XXIII. Unrecognized hero arrives home or in another country (definition - unrecognized arrival).

XXIV. False hero presents unfounded claims (definition - unfounded claims). 
XXV. Hero offered a difficult task (definition - a difficult task).

XXVI. The problem is solved (definition - the decision).

XXVII. Heroes learn (definition - recognition).

XXVIII. False hero or antagonist is exposed (definition - conviction).

XXIX. The hero is given a new look (definition - transfiguration).

XXX. The enemy is punished (definition - punishment).

XXXI. Hero marries and reigns (definition - wedding).

V. Propp also proved pairing (binary) most of the events / functions subjects (shortage - the elimination of shortages, ban - a violation of the ban, the fight - win, and so on.).

The "many functions logically combined by certain circles. These circles in general and consistent performers. This community action" [Propp, 1998, p.60]:

1) circle of action of the antagonist / villain (sabotage, or other forms of battle combat hero, prosecution);

2) circle of actions donor (preparation of transmission of a magical agent, supply the hero magical means);

3) circle of actions Assistant (spatial movement of the hero, the elimination of trouble or shortage, salvation from persecution, the resolution of the challenges transfiguration hero);

4) circle of action of the desired character (asking a difficult task, branding, exposure, recognition, the second sentence of the pest);

5) circle of behavior of the sender (the reference character);

6) circle action of the Hero (sending in the search, the response to the requirements of the donor's wedding);

7) circles actions of the false hero (sending in the search, the response to the requirements of the donor - is always negative - and, as a specific function - fraudulent claims) [Propp, 1998, p. 60-61].

Further research scientists [Eco, 1960; Zorkaya, 1981, 1994, and others] proved that Propp's approaches quite applicable to the analysis of many media texts, including nearly all of the mass media culture (literature, film, television and so on.). And it is true in many popular media texts in one way or another felt the echoes of biblical motifs of ancient Greek myths, fairy tales of Cinderella, Little Red Riding Hood, Serpent Dragon, Bluebeard, Ali Baba and the Forty Thieves, etc. Of course, the audience (eg, students) unconsciously reach for the fabulous, fantastic action, mythological heroes...

Taking advantage of the scheme of V. Propp, Umberto Eco [Eco, 1960, p.52] subjected to cultural and mythological and structural analysis of a series of spy novels about J ames Bond (the last half century almost all of them have been filmed, sometimes even several times, which resulted in a whole train of parodies).

The U. Eco's research results follow to stereotypical plot scheme:

A. Bond gets the job.

B. Bond meets with a villain(s).

C. Bond creates obstacles for first villains, or vice versa.

D. Bond meets a woman / beauty.

E. Bond uses Female (seduction mastery).

F. Villain takes captive Bond (with the woman or not).

G. Bond villain attempts (with a woman or not).

H. Bond wins.

I. Bond enjoys woman.

Continuing this analytical work I found in "Bond stories" 7 circles of actions (with V. Propp's classification):

1) circle of Villain's actions (persecution, insidious intrigues, the fight with Bond);

2) circle of Donor's actions (in each novel / series a head of the secret Engineering Laboratory presents Bond "magic bullet" in the form of modern espionage and other equipment, simultaneously demonstrating the features of its functioning);

3) circle of Assistant's actions (usually Woman / Beauty becomes Bond's assistant, and this Woman / Beauty helps Bond to escape from persecution, solve tricky task to find the desired object, etc.); 
4) circle of action of the desired object (this is often a military / strategic object that Bond want to destroy or steal);

5) circle of Sender's action (Head of the Secret Service sends Bond to another mission, but the sender's pretty secretary also includes in circle of this of action);

6) circle of Hero's action (Bond's dangerous assignment, the conquered women's hearts and bodies, the fight with the villain and his numerous servants, destruction of Villain);

7) false hero's circle (the false hero - as a rule - is a woman - Fatal Beauty. She always acts deception, sometimes pretending to be almost an ally and mistress of Bond. Fatal Beauty is closely linked with the wicked, and she almost always $100 \%$ confident in her power and victory over Bond. As a rule, her insidious actions lead to the fact that Bond life hangs in the balance, and it often saves only the Miracle).

This kind of cultural mythology can be easily detected in a variety of popular media texts. For example, extremely popular among the mass public television reality show Survivor is one of a modified versions: the "sender" (relatives and friends of the players), "heroes-seekers" (the players), "donor" (leading show), "assistants", etc.

You can select many of the above action characters circles (circles actions of sender, donor, hero, etc.) in many reality shows:

- Survivor and Heart of Africa: broken into teams participating in the show are the exotic countries - far from civilization, with no money, they are compelled to produce their own food and to perform a variety of tasks leading / donor in the hope of a final prize (the actions of the donor, the sender, the hero and so on.);

- Empire: the participants are divided into teams of rich and poor, one of them becomes the ruler of the Empire and, together with three of his retinue to enjoy the comfort and luxury of the castle; the rest of the show in peasant clothes live hut, performing heavy work and additional tasks "rich"; etc.

Literary-cycle simulation creative tasks relating to the cultural mythology of media texts on media education classes in the student audience:

Media agencies:

- the producer plan's drafting for the use of the mythological, fabulous foundations for new TV shows.

Media / media text categories:

- writing of synopsis (summary of future media text) using mythological, fairytale stereotypes (plot schemes, typical situations, characters, etc.).

Media technologies:

- writing of synopsis of the future of media texts with an emphasis on the use of modern technologies for creating media texts with mythological, fairy basis.

Media languages:

- writing of synopsis of the future media text with mythological, folk foundation with an emphasis on symbolic codes (frame, angle, etc.).

Media representations:

- drafting of the media text story with the (main or secondary) character having a mythological, fairy, folk source: preserving the features of his character, vocabulary, etc. The task is performed (as, indeed, most other media educational tasks character) on a competitive basis. At first, the audience meets a specific media texts, and then - writes stories with principal or secondary characters, and then brainstorm results, determined the most successful, close to the original stories.

Media audiences:

- drafting of the monologue from any members of the audience (different age, sex, social status, ethnicity, religion and so forth.) of media text with mythological, fairy, folklore source.

Cycle theatrical role-creative tasks for the analysis of media texts on cultural mythology of media education classes in the student audience:

Media agencies:

- role games on a film or TV show with a mythological, fairy, folk source (the various stages of preparation and film-making process); 
- role game "press conference" with "media text authors" ("producer", "writer", "director", "actors", "operator", "composer", "artist", "designer" and others), based on mythological, fairytale, folklore source: "journalists" ask "authors", they try to answer, etc .;

Media / media text categories: legends.

- role games on solutions of the same short story in the genres of fairy tales, myths and

Media technologies:

- role games: the dispute of "creators of media texts" about what specific technologies can be used in the creation of mythological, fairytale, folklore story.

Media languages:

- role games: the dispute of "creators of media text with a mythological, fairy, folk source", what specific codes (signs, symbols, etc.), visual and / or audio solution can be used when it is created;

Media representations:

- Students are playing the role of mythological, fairytale characters of media texts. Work is proceeding in groups of 2-3 people. Each group prepares and puts into practice your game project episode of a media text. The teacher acts as a consultant. The results are discussed and compared;

- role games: "interview" (interview with mythological / fairy tale characters of media texts and interviews with their "authors"). Work is proceeding in groups of 2-3 people. Each group prepares and puts into practice your game project interview. The teacher acts as a consultant. The results are discussed and compared.

Media audiences:

- role games: a sketch on the theme of the various reactions of specific members of the audience (different age, education level, social status, etc.) to certain media texts with a mythological, fairy, folk source.

Graphic-cycle simulation creative assignments for the analysis of media texts on cultural mythology of media education classes in the student audience:

Media agencies:

- preparing drawings / collages on the theme of the Agency's steps associated with the creation of media texts with mythological, fairytale, folklore source.

Media / media text categories:

- preparing drawings / collages, which could clearly imagine the kind of genre and media text with mythological, fairytale, folklore source.

Media technologies:

- preparing posters to media texts with a mythological, fairy, folk source, made in different techniques (drawing, collage, application, etc.).

Media languages:

- preparation of a series of frames / cards that could be used as a basis for the image (with the support of the various types of crop - the general plan, close-up, detail, etc.) proactive media text with mythological characters, fabulous, folklore source;

- creation of posters / collages / comics, visually reflecting the mythological basis of media texts.

Media representations:

- creation of posters / collages / comics, which were presented to the situation and the characters of media texts, based on mythological, fairytale, folklore source.

Media Audiences:

- preparation of pictures, which may be the representatives of the different types of audiences after contact with the media texts of different genres with mythological, fairy, folk source.

Cycle of literary and analytical creative tasks on cultural mythology of media texts on media education classes in the student audience:

Media agencies:

- analysis of socio-cultural factors that influenced the views of the agency / author of a particular media text, used the mythological, fairy basis.

Media / media text categories:

- separation of media texts (from the proposed teacher list) on the principle of relying on different plot of myths and fairy tales; 
- modeling (in tabular / structural form), based on researches of V. Propp, N. Zorkaya, M. Turovskaya, U. Eco, the mythological, fabulous stereotypes of media texts (narrative scheme, typical situations, characters, their values, ideas and gestures, clothes, objects, scene, etc.), considering the fact that many media texts are based on the same myths, fairy tales, legends.

Media technologies:

- analysis of a possible influence of modern technologies for creating media texts with mythological, fabulous foundation for their maintenance.

Media languages:

- analysis: how verbal and visual symbols in a media with mythological, folk form the basis of a certain value (for example, the role of signs in advertising);

- reading and analysis of symbolic codes (frame, angle, etc.) in a media text with mythological, folk basis; how the information relates to the codes and conventions of media text;

- analysis: how the symbolic codes may interact with each other to create a certain sense of media texts;

Media representations:

- put the character of media text (having mythological, fairytale, folklore source) into change situation (with a change of name, genre, time, place, action media text, its composition: climax, denouement, epilogue, etc.; age, gender, nationality character, etc.);

- analysis of media texts' advertising banners (visual and written information, the most important part of this information, the composition of the poster, the indication of the mythological, fabulous roots media text).

Media audiences:

- analysis of advertising posters and a prediction of success in the audience of a media text with mythological, fairytale, folklore sources.

Questions assignments for the analysis of media texts cultural mythology [Buckingham, 2003, pp.54-60, Silverblatt, 2001, pp.107-108; 2014; Fedorov, 2004, p.43-51; Potter, 2014; Fedorov, 2006, p.175-228]:

Media agencies:

Are media agencies use mythology when creating media texts? If so, how?

Media / media text categories:

What are the conventions of fairy-tale/ mythological genre?

Is there a predictable genre formula for media text, based on folklore sources? As understanding of this formula helps your perception of a particular media text?

What is the function of genre formula of media texts with mythological, fabulous foundation?

Media technologies:

Can a different technology for creating media texts relating to the myth, fairy tale, legend? Explain your answer.

Media languages: legends?

What is the specificity and / or visual solution in media texts based on myths, fairy tales,

Can you name the audio-visual codes, the most characteristic of media texts, with fabulous, mythological base?

Media representations:

Can you name specific media texts based on famous myths and fairy tales?

What is the impact of myths and fairy tales on the media text strings?

Can you formulate patterns of ties to media texts fairy / mythological genre?

What stereotypical stories, storylines conventions specific to media texts based on folklore, fairy, mythological sources?

What is the relationship between significant events and characters in a media text based on the myth, fairy tale, legend?

Media audiences:

What factors depends on the interpretation of the mass audience of media texts, based on folklore sources?

Can we say that the interpretation of media texts depends on psycho-physiological data personality? 
What are the causes of success with the audience the most famous media texts with a fabulous, mythological roots (genre, theme, emotional swings system, reliance on mythology, a happy ending, the calculation of the maximum coverage of the media preferences of the audience, etc.)?

As a cultural mythology of media texts affects the attitudes, values, and worldview of people?

\section{Conclusions}

In this article I presented the main directions for Cultural Mythology Analysis of media texts in the classroom at the student audience, including the examples of creative problems and issues associated with this type of this analysis in the context of media education problems, ie based on six key concepts of media literacy education: agency, category, language, technology, audience, representation. I suppose that the Cultural Mythology Analysis of media texts on media education classes can significantly develop media competence of students, including critical thinking and perception.

\section{References:}

1. Buckingham, D. (2003). Media Education: Literacy, Learning and Contemporary Culture. Cambridge, UK: Polity Press, 219 p.

2. Eco, U. (1960). Narrative Structure in Fleming. In: Buono, E., Eco, U. (Eds.). The Bond Affair. London: Macdonald, p.52.

3. Eco, U. (1976). A Theory of Semiotics. Bloomington: Indiana University Press.

4. Fedorov, A.V. (2001). Media Education: History, Theory and Methods. Rostov: CVVR, 2001. $708 \mathrm{p}$.

5. Fedorov, A.V. (2004). Specificity of media education of pedagogical students // Pedagogy. 2004. № 4, p.43-51.

6. Fedorov, A.V. (2006). Media Education: creative tasks for students and pupils // Innovation in Education. 2006. N 4, p.175-228.

7. Kostina, A.V. (2006). Mass culture as a phenomenon of the post-industrial society. Moscow: KomKniga, 352 p.

8. Nechay, O.F. (1993). Film education in the context of fiction // Specialist. 1993. № 5, p.11-13.

9. $\quad$ Philosophical Encyclopedic Dictionary (1983). Moscow, p.348.

10. Potter, W.J . (2014). Media Literacy. L.A.: Sage.

11. Propp, V.Y (1998). The morphology of the fairy tale. The historical roots of the fairy tale. Moscow: Labirint, 1998. 512 p.

12. Propp, V.Y. (1976). Folklore and reality. Moscow: Art, p. 51-63.

13. Razlogov, K.E. (1991). Paradoxes of commercialization // Screen and Stage. 1991. № 9, p.10.

14. Silverblatt, A. (2001). Media Literacy. Westport, Connecticut - London: Praeger, 449 p.

15. Silverblatt, A. (Ed.). (2014). The Praeger Handbook of Media Literacy (in 2 volumes). Santa Barbara, California and Oxford, England: Praeger.

16. Turovskaya, M.I. (1979). Why the viewer goes to the movies // Genres of Movie. Moscow: Art.

17. Yampolsky, M.V. (1987). Polemical notes about the aesthetics of the mass of the film // Transcript of the meeting of the "round table" of Film Critics, October 12-13, 1987. Moscow: Union of Cinematographers, p.31-44.

18. Zorkaya, N.M. (1981). Unique and replicated. Mass media and reproduced art. Moscow: Art, 1981. $167 \mathrm{p}$.

19. Zorkaya, N.M. (1994). Folklore. Splint. Screen. Moscow, 1994. 